\title{
Soil erosion risk mapping using RUSLE model on jhargram sub-division at West Bengal in India
}

\author{
Pravat Kumar Shit ${ }^{1}$ Arup Sankar Nandi ${ }^{2}$ Gouri Sankar Bhunia ${ }^{3}$
}

Received: 12 June 2015/Accepted: 13 July 2015/Published online: 11 September 2015

(C) Springer International Publishing Switzerland 2015

\begin{abstract}
An appraisal of spatial and quantitative information on soil erosion is a major challenge for human sustainability. The present study demonstrates the prognostic modeling capabilities of geo-spatial technology based on soil erosion potential model to assess the effects of implementing land use changes within sub-tropical region in India. The Revised Universal Soil Loss Equation (RUSLE) integrated with geo-spatial technology was used to produce predictive soil erosion map. Rainfall pattern, soil type, topography, crop system and management practices and geo-spatial data were used to predict the soil erosion model. Results shows $74.77 \%$ of the study area is marked as low potential zone for soil erosion, whereas $5.58 \%\left(>10 \mathrm{th}^{-1}\right.$ year $\left.^{-1}\right)$ is very high erosion risk zone. The present information may help recognizing areas that are vulnerable to soil loss and the proposed method will be used for generalized planning and assessment purposes for supervision and preserve the soil erosion.
\end{abstract}

Keywords Soil erosion - RUSLE model $\cdot$ Remote sensing data $\cdot$ GIS techniques $\cdot$ Soil conservation

Pravat Kumar Shit

pravatgeo2007@gmail.com

$\triangle$ Gouri Sankar Bhunia

rsgis_gouri@rediff.com

1 Department of Geography, Raja N.L.Khan Women's College, Gope Palace, Medinipur 721102, West Bengal, India

2 Department of Geography and Environment Management, Vidyasagar University, Medinipur 721102, West Bengal, India

3 Bihar Remote Sensing Application Centre, IGSC Planetarium, Bailey Road, Patna 800001, India

\section{Introduction}

Growing demands on the land and better understanding of human forces on the environment are foremost to reflective changes in land management (Millward and Merse 2001). Soil erosion by water has been an important global issue and major challenge for human sustainability in last decades (Prasannakumar et al. 2012). The importance of soil erosion is enhanced because of its adverse impact on agricultural production, water quality, hydrological systems and infrastructure due to both on-site and off-site damages (Pimentel 2006). Globally, 75 billion tons of soil is removed due to erosion, with most of its coming from agricultural land and as a result around 20 Mha of land is erased. Soil erosion is very high in Asia, Africa and South America averaging 30-40 $\mathrm{t} \mathrm{ha}^{-1}$ year $^{-1}$ (Pimentel 2006; Moncef et al. 2011). In the humid tropics of Asia, farmers grow subsistence crops in sloping land through highly erosive practices. An average rate of soil loss for Asia is $138 \mathrm{t} \mathrm{ha}^{-1}$ year $^{-1}$ (Chen et al. 2010; Sharma 2010). An estimated 175 Mha of land in India, constituting about $53 \%$ suffers from deleterious effect of soil erosion and other forms of land degradation. Active erosion caused by water and wind alone accounts for 150 Mha of land which accounts to loss of about 5.3 Mt of sub-soil per year. It is reported that approximately 25 Mha land have been degraded due to ravine, gullies, shifting cultivation, salinity, alkalinity and water logging (Reddy 1999). Dhruvanarayana and Rambabu (1983) have estimated that 5,334 Mt $\left(16.4 \mathrm{t} \mathrm{ha}^{-1}\right)$ of soil is detached annually and $29 \%$ is carried away by river into the sea and $10 \%$ is deposited in reservoirs resulting in the considerable loss of the storage capacity in India. In West Bengal, $14 \%$ of the area is affected by water erosion of which Puruliya is affected to the extent of 328 thousand hectare, followed by West 
Medinipur (218 thousand hectare), Bankura (199 thousand hectare), Koch Bihar (174 thousand hectare) and Jalpaiguri (132 thousand hectare) (Pandey et al. 2011). Various studies investigating the crop production have declined in the last few years due to soil erosion in western part of West Bengal in India (Nandi 2012; Mondal 2012).

Spatial and quantitative information on soil erosion prediction and assessment has been a challenge to researchers since the 1930s (Prasannakumar et al. 2012). The methods of quantifying soil loss based on erosion plots possess many limitations in terms of cost, representativeness and reliability of the resulting data. This trend has a noteworthy consequence on the advancement of underneath geo-spatial technology and modeling tools (Alexakis et al. 2013). These advances assist evaluation of deterrence practices based on the nature of the prevention measure (Kouli et al. 2009). Spatial analysis and model can also offer sustaining information for distribution of resources to those areas and forms of practices which will supply the most efficient fortification.

However, till date no studies have been reported the spatial distribution of soil loss due to the constraint of limited samples in complex environments. Conversely, mapping of soil erosion in large areas is often very difficult by traditional methods. The most commonly adopted empirical models are the Universal Soil Loss Equation (USLE) (Wischmeier and Smith 1965) and Revised Universal Soil Loss Equation (RUSLE) (Renard et al. 1991). Other models like the Erosion Productivity Impact Calculator (EPIC) (Williams et al. 1990), European Soil Erosion Model (EUROSEM) (Morgan et al. 1992) and Water Erosion Prediction Project (WEPP) (Flanagan and Nearing 1995) are also used to estimate the status of soil loss. The geo-spatial technology is cost-effective and timeefficient in this regard. Fewer studies have been carried out using different methods of GIS techniques and remotely sensed data are effective in identifying and mapping land degradation risks and modeling of soil loss (Pandey et al. 2007, 2009; Rahman et al. 2009; Nagaraju et al. 2011; Sinha and Joshi 2012; Nasre et al. 2013; Baroudy and Moghanm 2014; Jiang et al. 2015). The present study focused on the prognostic modeling capabilities of geospatial technology based soil erosion potential model to delineate the probable soil erosion potential areas in subtropical region.

\section{Description of the study area}

Jhargram Sub-division lies in Kasai-Subarnarekha river interfluves zone, located in the western part of Paschim Medinipur district of West Bengal (India). It is extended between $22^{\circ} 48^{\prime} 49^{\prime \prime}$ to $21^{\circ} 51^{\prime} 30^{\prime \prime} \mathrm{N}$ latitude and $86^{\circ} 33^{\prime} 50^{\prime \prime} \mathrm{E}$ to $87^{\circ} 15^{\prime} 31^{\prime \prime} \mathrm{E}$ longitude. The study area consists of eight blocks, namely Binpur-I, Binpur-II, Jamboni, Jhargram, Gopiballavpur-I, Gopiballavpur-II, Sankrail and Nayagram (Fig. 1). The total area of the study site is about $3037.64 \mathrm{~km}^{2}$ and an average elevation of $65 \mathrm{~m}$. The study site is mainly controlled by Kasai (Kangsabati) and Subarnarekha rivers along with their tributaries. It represents regional diversities in terms of physiographic, agro-climatic characteristics, economic development and social composition etc. This region is a part of residual Chhotonagpur plateau with undulating relief, laterite soil and humid climate. Physiographically, the region can be categorized into three parts, viz Chotonagpur flanks with hills, and rolling lands in the western part, Rahr plain with lateritic uplands in the middle part (Shit et al. 2012; Gayen et al. 2013). The soil is mainly sandy loam type and the average land slope varied between 5 and $8 \%$. The area experiences very hot summer with temperature reaching up to $45{ }^{\circ} \mathrm{C}$ in May and June. The annual average rainfall during monsoon season varies between 997.3 and $1354.7 \mathrm{~mm}$ and $85 \%$ of the rainfall occurs during the monsoon season (June to October). Lands are mostly mono-cropped, having only limited surface irrigation facilities. The dominant crop in the study area is paddy. Erosion problem is prevalent in the study area due to rolling topography and improper agricultural management practices.

\section{Material and method}

\section{Data used and pre-processing}

The Survey of India (SOI) topographical sheets of the study area $(73 \mathrm{~J} / 9,10,14,15,16 ; 73 \mathrm{~N} / 2,3,4,7$; and 73O/1; scale of 1:50,000) were collected. The scanned topographic maps were geometrically corrected by geographic projection system with Modified Everest datum based on second order polynomial algorithm. Shuttle Radar Topographic Mission (SRTM) was collected to generate the Digital Elevation Model (DEM) of the study area. These data have been acquired to generate digital topographic maps and seamless DEMs of homogeneous quality in 3-arc seconds (30 m) spatial resolutions (Rabus et al. 2003). A digital elevation model (DEM) represents in Fig. 3a for spatial variation in altitude.

\section{Generation of land use/land cover map (LULC)}

Land use/land cover is very important for runoff estimation and soil loss. The Landsat4-5 Thematic Mapper data (Spatial resolution-30 m; Path/Row- 139/44 and 139/45) was used for preparing land use/land cover map derived 


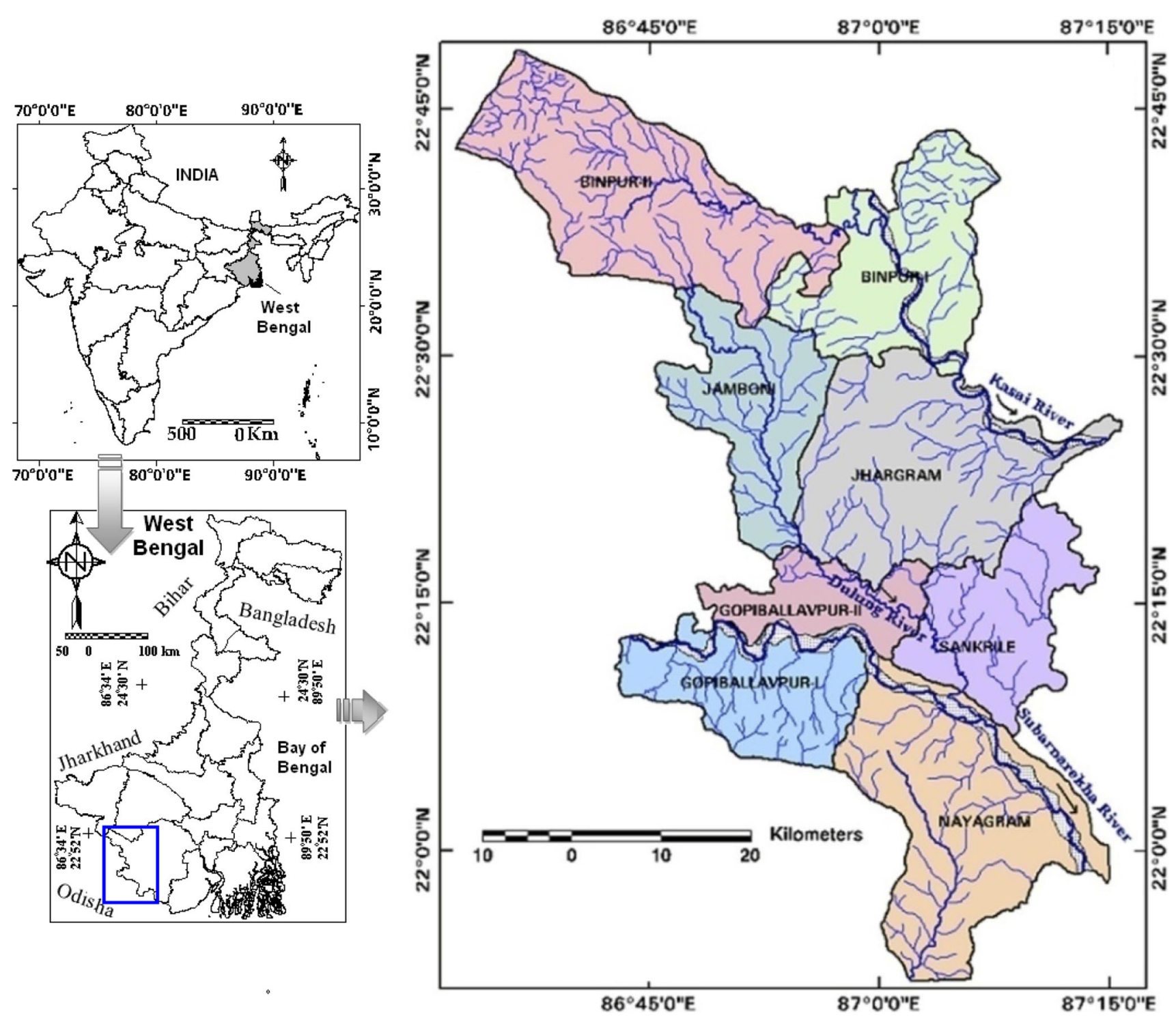

Fig. 1 Location of study area

from United State Department of the Interior, United State Geological Survey (http://earthexplorer.usgs.gov/). Supervised classification system with maximum likelihood classifier (MLC) algorithm of ERDAS IMAGINE v.8.5 was used for digital classification of satellite data (Shit et al. 2015). The maximum likelihood classification algorithm assumes that spectral values of training pixels are statistically distributed according to a multivariate normal (Gaussian) probability density function. Consequently, classification results were then assessed for accuracy using ground control-points determined in the study area collected through hand-held Garmin Global Positioning System (GPS) (accuracy $\pm 3 \mathrm{~m}$ ) (Wu and shao 2002). Validation with Google Earth and field control-points ensured that classes were properly assigned to the respective land cover feature on the ground (Rogan et al. 2002). In the present study following LULC classes were considered: water, wet fallow land, dense forest, low dense forest, degraded forest, dry fallow land, agricultural fallow and cultivated land.

\section{Soil Erosion Estimation Model}

The revised universal soil loss equation (RUSLE) model (Eq. 1) was adopted to assess the soil erosion prescribed by Renard et al. (1997).

$\mathrm{A}=\mathrm{R} \times \mathrm{K} \times \mathrm{L} \times \mathrm{S} \times \mathrm{C} \times \mathrm{P}$

where $\mathrm{A}$ is the soil loss in $\mathrm{t} \mathrm{ha}^{-1}$ year $^{-1}$; $\mathrm{K}$ is the soil erodibility factor, $\mathrm{R}$ is the rainfall-runoff erosivity factor; 
$\mathrm{S}$ is the slope steepness factor; $\mathrm{L}$ is the slope length factor and $\mathrm{C}$ is the cover and management factor; $\mathrm{P}$ is the conservation practices factor. The $\mathrm{L}, \mathrm{S}, \mathrm{C}$ and $\mathrm{P}$ values are dimensionless. All these factors (RKLSCP) were integrated into GIS environment for generation of soil erosion prediction map. The proposed methodology of soil erosion model is shown in Fig. 2.

\section{Rainfall erosivity $(R)$}

The rainfall data since last 35 years (1976-2010) from Indian Meteorological Department (IMD, Pune) were used for calculating R-factor. In the present study, spatial distribution of $R$-factor is assumed to be uniform. To calculate the R-factor Wischmeier and Smith (1978) and Arnoldus (1980) methods have been followed (Eq. 2):

$R=\sum_{i=1}^{12} 1.735 \times 10^{\left[1.5 \log _{10}\left(p_{i}^{2} / p\right)-0.08188\right]}$

where, $R$ is rainfall erositivity factor in $\mathrm{MJ} \mathrm{mm} \mathrm{ha}{ }^{-1} \mathrm{~h}^{-1}$ year $^{-1}, P_{\mathrm{i}}$ is monthly rainfall in $\mathrm{mm}$ and $P$ is annual rainfall in $\mathrm{mm}$.

\section{Soil erodibility factor $(K)$}

The soil erodibility factor $(\mathrm{K})$ represents both susceptibility of soil erosion and the amount and rate of runoff measured under standard plot condition. Soil erodibility factor $(K)$ in RUSLE model was estimated by Wischmeier et al. (1971) model. Soil texture is classified based on United States Department of Agriculture (USDA) techniques. The referenced soil map derived from National Atlas and Thematic Mapping Organization (NATMO), Department of Science and Technology, Government of India was used to estimate the $\mathrm{K}$ factor. The corresponding $\mathrm{K}$ values for the

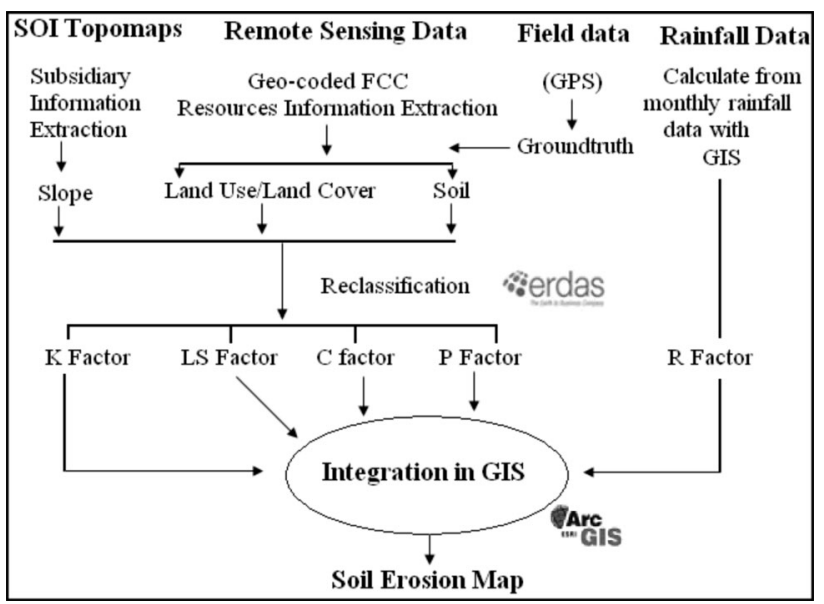

Fig. 2 Flow chart for the generation of soil erosion map soil types were identified from the soil erodibility monograph (USDA 1978), considering the particle size, organic matter content and permeability class.

\section{Topographic factor (LS)}

Topographic factors like, slope length factor (L) and slope steepness factor (S) mainly reflect the effect of surface topography on erosion (Yildirim 2012; Shit et al. 2015). Slope length is defined as the horizontal distance from the point of origin of overland flow to the point where either the slope gradient decreases enough that deposition begins, or runoff is concentrated in a defined channel (Renard et al. 1997; Wischmeier and Smith 1978). Slope steepness reflects the influence of slope gradient on erosion. In general, an increase in the $\mathrm{L}$ and/or $\mathrm{S}$ factor produces higher overland flow velocities and correspondingly greater erosion (Ozsoy et al. 2012). Generating the L and S values poses the largest problem (Moore and Wilson 1992). The slope length (L) and slope steepness (S) derived from SRTM DEM model. In ArcGIS (Arcview software 3.2.), spatial analyst and Hydrotool extension tools (Moore and Burch 1986) were used to estimate the $\mathrm{L}$ and $\mathrm{S}$ factor. To calculate the L-factor McCool et al. (1987) model was followed (Eq. 3).

$L=\left(\frac{\lambda}{22.13}\right)^{m}$

where, $\mathrm{L}$ is slope length factor; $\lambda$ is field slope length (m); $\mathrm{m}$ is dimensionless exponent that depends on slope steepness. 22.13 is the RUSLE unit plot length $(\mathrm{m}) ; \mathrm{m}$ is a variable slope length exponent.

The $S$-factor was calculated based on the relationship given by McCool et al. (1987) for slope longer than $4 \mathrm{~m}$ as:

$S=10.8 \sin \theta+0.03$ if $\theta \leq 5^{\circ}$

$S=16.8 \sin \theta-0.5 \quad$ if $\theta>5^{\circ}$

$S=21.91 \sin \theta-0.96$ if $\theta \leq 10^{\circ}$

where $\mathrm{S}$ is slope steepness factor and $\theta$ is slope angle in degree. The slope steepness factor is dimensionless. The $\mathrm{L}$ and $\mathrm{S}$ factors were calculated by Raster Calculator tool in ArcGIS. Then, the LS factor raster layer was further generated by multiplying $\mathrm{L}$ factor and $\mathrm{S}$ factor.

\section{Crop management factor $(C)$}

The cover management factor $(C)$ is a crucial factor to the erosion because it is a readily managed condition to reduce erosion (Renard et al. 2011; Chatterjee et al. 2014). Soil erosion decreases exponentially with increase in vegetation cover (Jiang et al. 2015; Shit et al. 2013). Plant cover reduces soil erosion by intercepting raindrops, enhancing 
Fig. 3 Spatial distribution of factors of RUSLE model, a Digital elevation model (DEM); b K factor; c LS factor; d $\mathrm{C}$ factor; and e land use land cover (LULC)
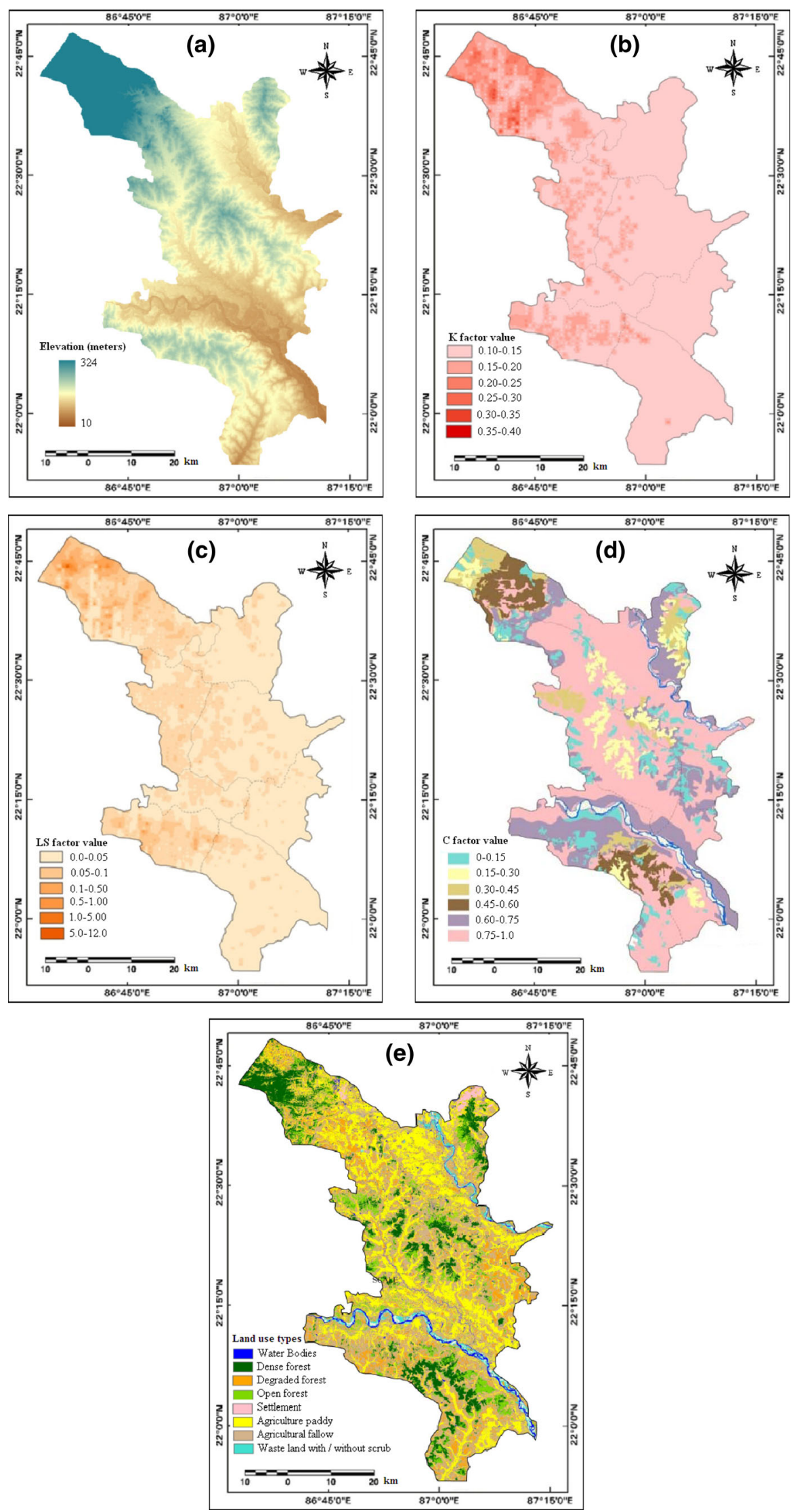
Table 1 Soil erosion category on elevation zones (Percentage of area, \%)

\begin{tabular}{lccccc}
\hline Elevation zone $(\mathrm{m})$ & Slight/low & Moderate & High & Very high & Total \\
\hline$<60$ & 1.24 & 0.67 & 0.52 & 0.31 & 2.74 \\
$60-120$ & 5.27 & 1.27 & 0.94 & 0.61 & 8.09 \\
$120-180$ & 10.10 & 2.58 & 1.06 & 0.94 & 14.68 \\
$180-240$ & 21.54 & 3.50 & 1.48 & 1.02 & 27.54 \\
$240-300$ & 27.20 & 5.22 & 2.00 & 1.50 & 35.92 \\
$>300$ & 9.42 & 1.17 & 0.24 & 0.2 & 11.03 \\
Total & 74.77 & 14.41 & 6.24 & 4.58 & 100 \\
\hline
\end{tabular}

Table 2 Land use/Land cover statistics of the study area

\begin{tabular}{|c|c|c|c|c|c|}
\hline Land use/Land cover class & Area (ha) & Percentage $(\%)$ & Producer accuracy $(\%)$ & User accuracy $(\%)$ & $\mathrm{Kappa}^{\wedge}$ \\
\hline Water body & 8299.93 & 2.71 & 66.67 & 66.67 & 0.65 \\
\hline Waste land with/without scrub & 8212.33 & 2.69 & 100.00 & 66.67 & 1.00 \\
\hline Dense forest & $30,721.66$ & 10.04 & 71.43 & 83.33 & 0.68 \\
\hline Degraded forest & $40,868.07$ & 13.36 & 84.21 & 100.00 & 0.77 \\
\hline Open forest & $23,700.64$ & 7.75 & 100.00 & 88.89 & 1.00 \\
\hline Settlement/built-up area & 6154.74 & 2.01 & 100.00 & 66.67 & 1.00 \\
\hline Agriculture paddy & $91,320.93$ & 29.86 & 66.67 & 100.00 & 0.65 \\
\hline Agriculture fallow/Barren land & $100,577.48$ & 31.58 & 100.00 & 80.00 & 1.00 \\
\hline Total & $305,855.80$ & 100.00 & & & 0.8265 \\
\hline
\end{tabular}

Overall classification accuracy $=86.00 \%$. Overall kappa statistics $=0.8265$

infiltration, slowing down the movement of runoff (Gyssels et al. 2005; Wang et al. 2013). The crop management factor (C) is the ratio of soil loss from an area with specified cover and management to soil loss from an identical area in tilled continuous fallow. The traditional method for spatial estimation of $\mathrm{C}$ factor is assigning values to land cover classes using classified remotely sensed images of study areas (Table 3). To calculate the $\mathrm{C}$ factor normalized difference vegetation index (NDVI) was used proposed by Van de Knijff et al. (2000) (Eq. 5):

$C=\exp \left[-a \frac{\mathrm{NDVI}}{(b-\mathrm{NDVI})}\right]$

where $a$ and $b$ are unit less parameters that determine the shape of the curve relating to NDVI and C factor.

\section{Conservation practice factor $(\mathbf{P})$}

Conservation practice factor $(\mathrm{P})$ is defined as the ratio of soil loss after a specific support practice to the corresponding soil loss after up and down cultivation. Farming practices area are delineated using Landsat Thematic Mapper data. The $P$ value was obtained from the standard table proposed by USDA-SCS (United States Department of Agriculture-Soil Conservation Service) (1972) and Rao (1981). The lower the $\mathrm{P}$ value, the more effective the conservation practices.

\section{Results and discussion}

Soil erosion by several geographical factors is more evident precarious threat in sub-tropical region of India. Livelihood of the people in this region is primarily reliant on intensive subsistence agriculture. Hence, estimation and representing of soil erosion prone area are very essential for its conservation and management. In the present study, both the qualitative and quantitative tactics were implemented to assess soil erosion risk.

The elevation map (DEM) is shown in Fig. 3a. Categorization of soil erosion characteristics in relation to different elevation zones is illustrated in Table 1. Approximately $63.46 \%$ soil erosion area was recorded in the elevation zone between 180 and $300 \mathrm{~m}$. Consequently, $14.68 \%$ erosion area was evidenced in the elevation zone between 120 and $180 \mathrm{~m}$. Therefore, it is necessary to take conservation practices in the zone between 120 and $350 \mathrm{~m}$ to lessen soil forfeiture in the study area.

In the present study, nine LULC classes were generated (Fig. 3e). The result showed most of the area $(61.44 \%)$ covered with agricultural paddy and agricultural fallow land. Dense forests were found in the north-west and southern part of the study site and covered with $10.04 \%$. The spatial distribution of LULC classes illustrated in Fig. 3 and the area statistics is presented in Table 2. The overall accuracy of LULC classes is calculated as $86.00 \%$ 
Table 3 Soil erosion category on land use types (Percentage of area, \%)

\begin{tabular}{lccllc}
\hline Land use type & Slight/low & Moderate & High & Very high & Total \\
\hline Water body & 0.1 & 0.0 & 0.0 & 0.0 & 0.1 \\
Waste land with/without scrub & 15.8 & 2.6 & 1.4 & 1.8 & 21.6 \\
Dense forest & 2.7 & 0.4 & 0.2 & 0.0 & 3.3 \\
Degraded forest & 9.61 & 0.9 & 0.5 & 0.3 & 11.31 \\
Open forest & 14.06 & 1.01 & 0.6 & 0.5 & 16.17 \\
Settlement/built-up area & 1.8 & 0.8 & 0.3 & 0.0 & 2.9 \\
Agriculture paddy & 7.8 & 2.6 & 1.44 & 0.82 & 13.16 \\
Agriculture fallow/Barren land & 22.9 & 6.1 & 1.8 & 1.16 & 32.46 \\
Total & 74.77 & 14.41 & 6.24 & 4.58 & 100 \\
\hline
\end{tabular}

based on 50 random samples representing various LULC categories. Agricultural land as the primary land use type increases due to human intervention and increasing population pressure in the study area. The association between soil loss in relation to different land use category in the study area was assessed (Table 3). The analysis illustrates that the agriculture fallow/barren land and waste land with/ without scrub contributed 32.46 and $21.0 \%$ respectively of total soil loss owing to its large erosion rate. Open forest $(16.17 \%)$, degraded forest $(11.31 \%)$ and agricultural paddy $(13.16 \%)$ land were under unadorned to extreme erosion categories. Therefore it is needed to carry out the conservation practices on these land use types taking into consideration their large areas and mass soil loss. Suitable cropping pattern and crop rotation practice may be commenced and community based soil erosion management program should be introduced to ease the soil loss in the study site. Conservation tillage, in conservation planning, contour bandings or contour hedgerows should be given to agronomic measures of soil conservation (Sharma 2010). On the other hand, dense forests play an important role in soil conservation. Therefore, the afforestation program in this region is essential and should be implemented strictly (Sharma 2010; Bhunia and Shit 2013; Jiang et al. 2015).

The calculated $\mathrm{R}$ factor for the study area is shown in Table 4. The rainfall erosivity factors $(\mathrm{R})$ for the years 1976-2010 ranges between 924.60 and 10,277.87 MJ mm ha ${ }^{-1} \mathrm{~h}^{-1}$ year $^{-1}$. The average $\mathrm{R}$ factor was $4,098.35 \mathrm{MJ} \mathrm{mm} \mathrm{ha}^{-1} \mathrm{~h}^{-1}$ year $^{-1}$ (Table 2). The highest value $\left(10,277.87 \mathrm{MJ} \mathrm{mm} \mathrm{ha}{ }^{-1} \mathrm{~h}^{-1}\right.$ year $\left.^{-1}\right)$ of $\mathrm{R}$ factor was recorded in 1976 and the lowest value (924.60 MJ mm ha ${ }^{-1} \mathrm{~h}^{-1}$ year $^{-1}$ ) of $\mathrm{R}$ factor was documented in 1998.

Earlier studies endeavored to guesstimate $\mathrm{K}$ factor based on soil types (Symeonakis and Drake, 2010). K values for the textural groups varied from $0.10 \mathrm{t}$ ha h ha ${ }^{-1} \mathrm{MJ}^{-1} \mathrm{~mm}^{-1}$ (gravelly loam), $0.17 \mathrm{t}$ ha h ha ${ }^{-1} \mathrm{MJ}^{-1} \mathrm{~mm}^{-1}$ for gravelly clay, $0.25 \mathrm{t} \mathrm{ha} \mathrm{h} \mathrm{ha}{ }^{-1} \mathrm{MJ}^{-1} \mathrm{~mm}^{-1}$ for clay and $0.36 \mathrm{t}$ ha h ha ${ }^{-1} \mathrm{MJ}^{-1} \mathrm{~mm}^{-1}$ for loam, respectively. The magnitude and the spatial distribution of soil erodibility $(\mathrm{K})$ are illustrated in Fig. 3b. The maximum value of $\mathrm{K}$ recorded in the northern part o the study site and the minimum value portrayed in the eastern and southern part of the study site.

The spatial distribution of LS factor is shown in Fig. 3c. The entire study area is classified into six categories based on geometric interval. Topographic factor of the study site ranged between 0.0 and 12.0. In the study area, the extreme northern part showed the highest slope whereas, the lower slope found on the eastern and southern part. Moderate slope of topography were found in the central and western part of the study site. Slope is another imperative factors contribution soil loss in the study site. The soil loss and erosion category on different slope gradient zones were also assessed (Table 5). The analysis shows that $15-25^{\circ}$ slope portrays $38.36 \%$ of soil loss in the study site and the slope of $8-15^{\circ}$ accounting for nearly $28.38 \%$ of total erosion area. The slight erosion categories are mostly observed in the zone with slopes less than $3^{\circ}$. The very high soil erosion categories are seen in the zone with slopes between 15 and $25^{\circ}$, moderate and the low erosion category are mostly in the zone with slopes less than 15 and $8^{\circ}$ respectively. The correlation analysis of erosion rate with slope and elevation in the study area revealed that the interrelationship between erosion and slope was very significant $(r=0.72, P<0.001)$. The present results also incorporated the previous study by Jiang et al. (2015).

Crop management factor (C) has been found to be good proxy for land cover on somewhat large basins and were smeared in numerous expanses (Van Rompaey et al. 2005). The magnitude and the spatial distribution of $\mathrm{C}$ show values between 0.01 and 1.0 (Fig. $3 \mathrm{~d}$ ). The values for $\mathrm{C}$-factor were assigned to be 0.70 for area under paddy cultivation and 0.45 for forest area (Table 6). The highest (poor land cover management) almost coincide with the lowest NDVI values, (0.60-0.05), since forest protects soils against erosion, while the open rangeland exposed to plowing has a high $C$ value (0.30). Similarly, the mixed rain-fed areas have a $C$ value of (0.35). The model showed logical results after applying the assumed $C$ values for each 
Table 4 Annual rainfall erosivity factor $\left(\mathrm{MJ} \mathrm{mm} \mathrm{ha}^{-1}\right.$ $\mathrm{h}^{-1}$ year $^{-1}$ ) of the study area

\begin{tabular}{|c|c|}
\hline Year & R-factor \\
\hline 1976 & $10,277.87$ \\
\hline 1977 & 7716.00 \\
\hline 1978 & 8798.00 \\
\hline 1979 & 2455.56 \\
\hline 1980 & 2301.90 \\
\hline 1981 & 3168.03 \\
\hline 1982 & 3149.13 \\
\hline 1983 & 1642.97 \\
\hline 1984 & 7222.47 \\
\hline 1985 & 3673.70 \\
\hline 1986 & 2713.56 \\
\hline 1987 & 3380.46 \\
\hline 1988 & 4112.43 \\
\hline 1989 & 3225.57 \\
\hline 1990 & 3155.12 \\
\hline 1991 & 4508.18 \\
\hline 1992 & 3767.12 \\
\hline 1993 & 2691.58 \\
\hline Year & R-factor \\
\hline 1994 & 4816.38 \\
\hline 1995 & 2385.17 \\
\hline 1996 & 3081.70 \\
\hline 1997 & 5730.25 \\
\hline 1998 & 924.60 \\
\hline 1999 & 3623.21 \\
\hline 2000 & 2735.72 \\
\hline 2001 & 2438.83 \\
\hline 2002 & 3122.23 \\
\hline 2003 & 3485.61 \\
\hline 2004 & 3764.78 \\
\hline 2005 & 3222.85 \\
\hline 2006 & 2607.91 \\
\hline 2007 & 8393.03 \\
\hline 2008 & 9534.4 \\
\hline 2009 & 3837.97 \\
\hline 2010 & 1778.09 \\
\hline Average & 4098.35 \\
\hline
\end{tabular}

land-cover class, with a trend of increasing erosion with low vegetation cover.

\section{Spatial distribution of soil loss}

The revised universal soil loss equation is a straight forward and empirically based model that has the ability to predict long term average annual rate of soil erosion on slopes using rainfall pattern, soil type, topography, crop system and management practices. In the present research, annual soil erosion rate map was generated for Jhargram
Table 5 Soil erosion category on different slope zones (Percentage of area, \%)

\begin{tabular}{lccccc}
\hline Slope (degree) & Slight/low & Moderate & High & Very high & Total \\
\hline$<3$ & 3.94 & 0.84 & 0.39 & 0.17 & 5.34 \\
$3-8$ & 11.68 & 1.48 & 0.73 & 0.68 & 14.57 \\
$8-15$ & 21.84 & 3.84 & 1.54 & 1.16 & 28.38 \\
$15-25$ & 27.98 & 6.11 & 2.48 & 1.79 & 38.36 \\
$>25$ & 9.33 & 2.14 & 1.10 & 0.78 & 13.35 \\
Total & 74.77 & 14.41 & 6.24 & 4.58 & 100 \\
\hline
\end{tabular}

Table 6 Crop management factor for different land use/land cover classes

\begin{tabular}{ll}
\hline Land use/land cover & C-factor \\
\hline Water body & 0.0 \\
Waste land with/without scrub & 0.33 \\
Dense forest & 0.004 \\
Degraded forest & 0.008 \\
Open forest & 0.008 \\
Settlement/built-up area & 0.002 \\
Agriculture paddy & 0.28 \\
Barren land/agriculture fallow & 1.0 \\
\hline
\end{tabular}

Source: USDA-SCS (1972), Rao (1981)

sub-division which is characterized by undulating terrain characteristics and lateritic soil.

Potential annual soil loss is estimated based on R, K, LS, $\mathrm{C}$ and $\mathrm{P}$ in GIS environment. The estimated average soil erosion rate for the Kasai-Subarnarekha river interfluves zone ranges between 0 and $13.28 \mathrm{th}-1 \mathrm{y}-1$ (Fig. 4). The estimated average annual soil loss of study area was grouped into four classes based on the minimum and maximum values and the spatial distribution of probable soil loss is portrayed in Fig. 5. The results of our analysis showed $74.77 \%$ of the study area is marked as low potential erosion $(<2.0 \mathrm{t} \mathrm{h}-1 \mathrm{y}-1) ; 14.41 \%$ area manifested as moderate erosion (2.0-5.0 t h-1 y-1) and remaining part is considered as high $(6.24 \%, 5.0-10.0 \mathrm{t} \mathrm{h}-1 \mathrm{y}-1)$ to very high $(5.58 \%,>10 \mathrm{t} \mathrm{h-1} \mathrm{y-1)} \mathrm{erosion} \mathrm{risk} \mathrm{(Table} \mathrm{7).}$

Block wise distribution of soil erosion in the study area is summarized in Table 8 and Fig. 5. The results showed all the study blocks come under the moderate erosion hazard (i.e., ranged from $7.85 \%$ to $24.12 \%$ ) except Gopiballavpur-I and Binpur-I. Conversely, five blocks, namely Gopiballavpur-II, Jamboni, Binpur-I, Binpur-II and Nayagram comes under high erosion hazard zone which is ranged from 4.04 to $8.50 \%$ of the total area (Fig. 6). As such, Binpur-I, Binpur-II, Jamboni, Nayagram and Gopiballavpur-II falls under very high erosion hazard zone. However, the area with the maximum 
gradient is mostly covered with high fraction of vegetation, and vice versa (Fig. 6). Table 9 is representing the general soil erosion management strategies of the study area. Therefore, information derived in this study essential to practice prudently used for local level soil preservation planning.

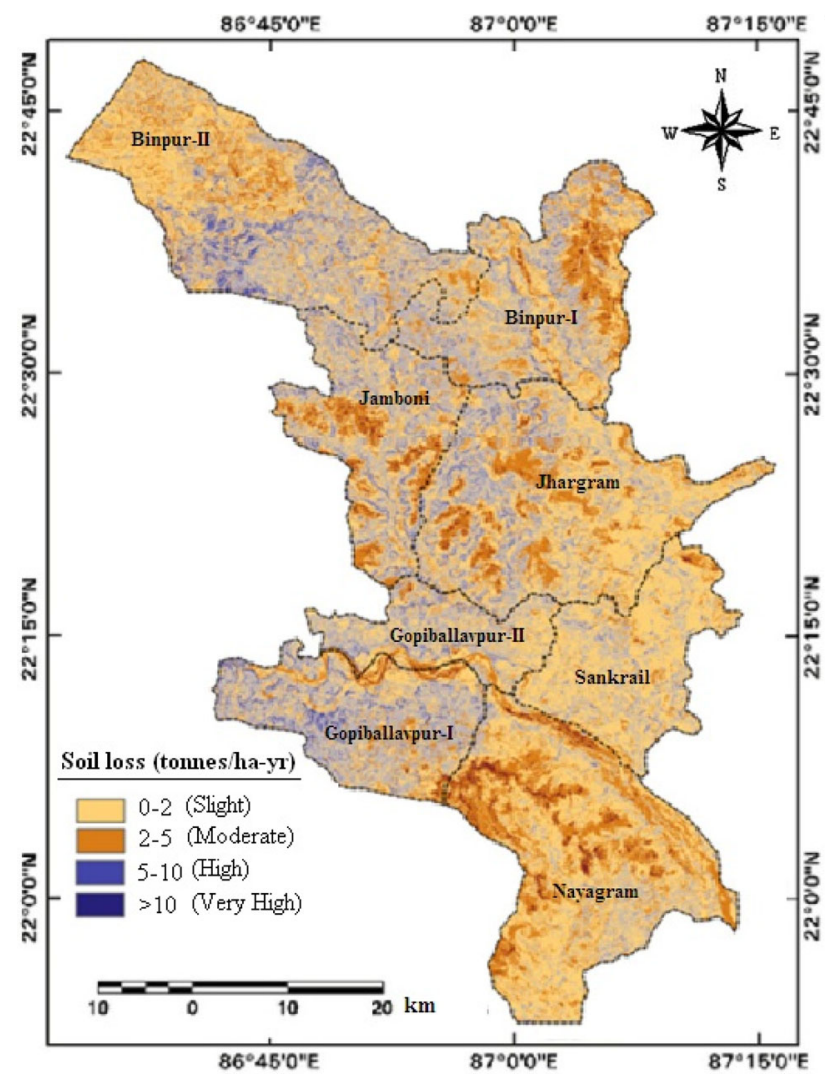

Fig. 4 Spatial distribution of soil erosion

\section{Conclusions}

Soil erosion in Kasai-Subarnarekha river interfluves zone is a serious dilemma and assessment of soil loss is indispensable for conservation of land and water for the sustainable development. As the erosion process of soil is very slow and relatively ignored, and it may arise at an disquieting rate originating severe loss of top soil. Quantitative estimation of soil loss by water erosion in the study area was modeled by accomplishment spatial soil erosion risk modeling using RULSE model with the aid of remote sensing and GIS. However, all the thematic layers (e.g., C-factor i.e., all agricultural land was classified as crop fallow rotation; calibration of grid cell size which affect the LS factor) of the model contain approximations and generalizations of data to some extent. Present study reveals that the annual soil erosion was recorded as $>10$ ton $\mathrm{ha}^{-1}$ year $^{-1}$ from waste land with/without lateritic undulating terrain; while the agricultural fallow land/barren land represented as 5-10 ton $\mathrm{ha}^{-1}$ year $^{-1}$. The developed soil erosion map may be helpful for the proper planning and management of future soil erosion disasters and LULC planning. Soil erosion is serious in the elevation zone between 180 and $300 \mathrm{~m}$ and slope zone with slopes between 8 and $25^{\circ}$. In terms of land use, agriculture fallow/ barren land and waste land with/without scrub contributed mass majority to total soil loss. Soil losses are reasonably stumpy in dense forest area. About 4.58 percent (14026.00 hectare) of total area of basin area was found under very high risk ( $>10.0$ ton $\mathrm{ha}^{-1}$ year $^{-1}$ ) of erosion. Around 6.24 percent (19120.75 hectare) of basin lies in moderate risk of erosion (5.1-10.0 ton $\mathrm{ha}^{-1}$ year $^{-1}$ ). Very high risk of erosion is observed in Binpur-II block while, the low risk is documented from Gopiballvpur-I block; it might be
Fig. 5 Block wise distribution of soil erosion risk

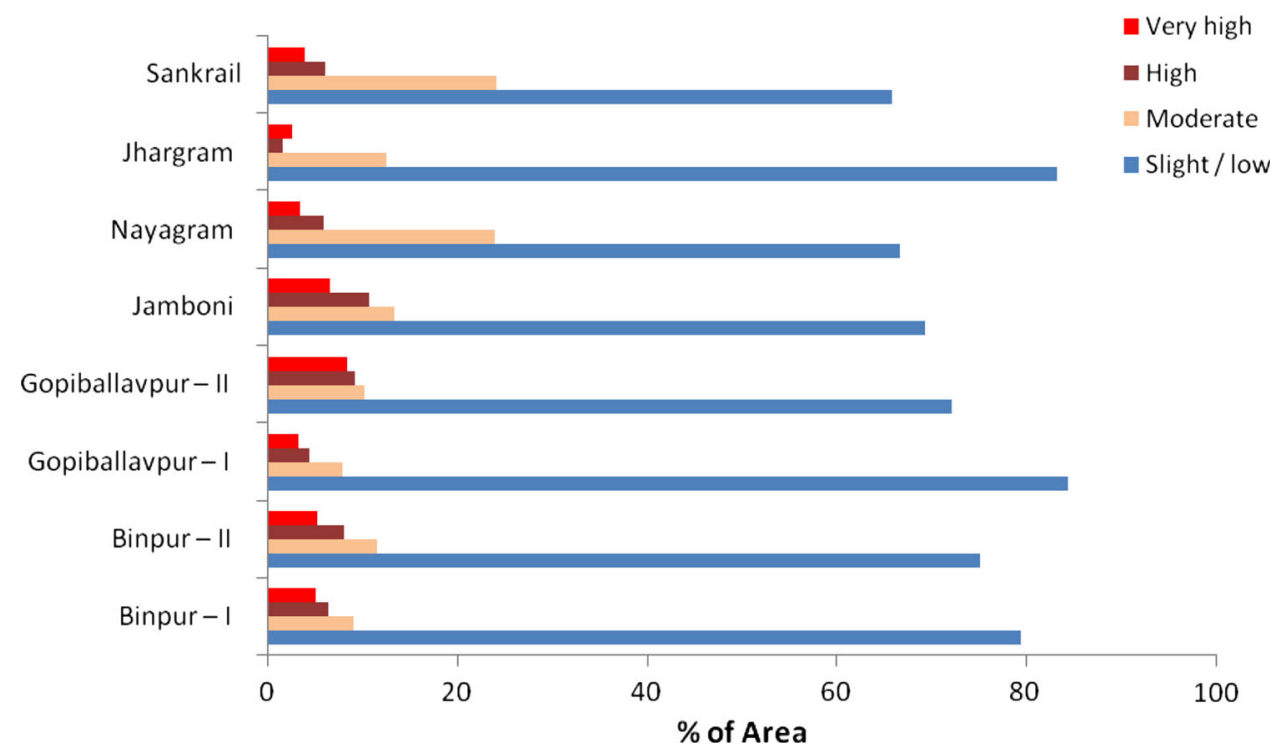


Table 7 Average rate of soil loss of the study area

\begin{tabular}{llccc}
\hline Erosion class & Rate of soil loss $\left(\right.$ ton $\left.\mathrm{ha}^{-1} \mathrm{year}^{-1}\right)$ & Area in hectare & \% of the total area & Cumulative $\%$ \\
\hline Slight/low & $<2.0$ & $229,023.26$ & 74.77 & 74.77 \\
Moderate & $2.1-5.0$ & $44,135.03$ & 14.41 & 89.18 \\
High & $5.1-10.0$ & $19,120.75$ & 6.24 & 95.42 \\
Very high & $>10.1$ & $14,026.00$ & 4.58 & 100 \\
Total & & 30,6305 & 100 & \\
\hline
\end{tabular}

Table 8 Block wise average rate of soil loss of the study area (ha)

\begin{tabular}{llrlr}
\hline Blocks & \multicolumn{4}{l}{ Soil erosion (area in hectare) } \\
\cline { 2 - 5 } & Slight/low & Moderate & \multicolumn{1}{l}{ High } & Very high \\
\hline Binpur-I & $28,732.53$ & 3321.44 & 2306.88 & 1882.15 \\
Binpur-II & $43,240.92$ & 6644.72 & 4644.72 & 3044.46 \\
Gopiballavpur-I & $22,950.32$ & 2138.22 & 1217.07 & 913.61 \\
Gopiballavpur-II & $14,773.02$ & 2100.86 & 1881.15 & 1742.97 \\
Jamboni & $22,631.54$ & 4379.32 & 3510.55 & 2138.59 \\
Nayagram & $33,658.34$ & 12143.89 & 3028.68 & 1729.09 \\
Jhargram & $44,879.22$ & 6749.36 & 861.12 & 1460.30 \\
Sankrail & $18,157.37$ & 6657.22 & 1670.58 & 1114.83 \\
\hline
\end{tabular}

because high management practice. The information derived in the study may help identifying areas that are vulnerable to soil loss and the proposed method will be used further for generalized planning and assessment purposes. Model appraised erosion assessments were sound complemented with field based existing erosion damage calculation. The description of the ranking system for the geographical factor is very straightforward and easy to activate without entailing luxurious time overwhelming experimentation. Present information provided very glowing approximation of erosion patterns at landscape scale. This method should combine land use strategies for each zone with careful consideration of certain structural
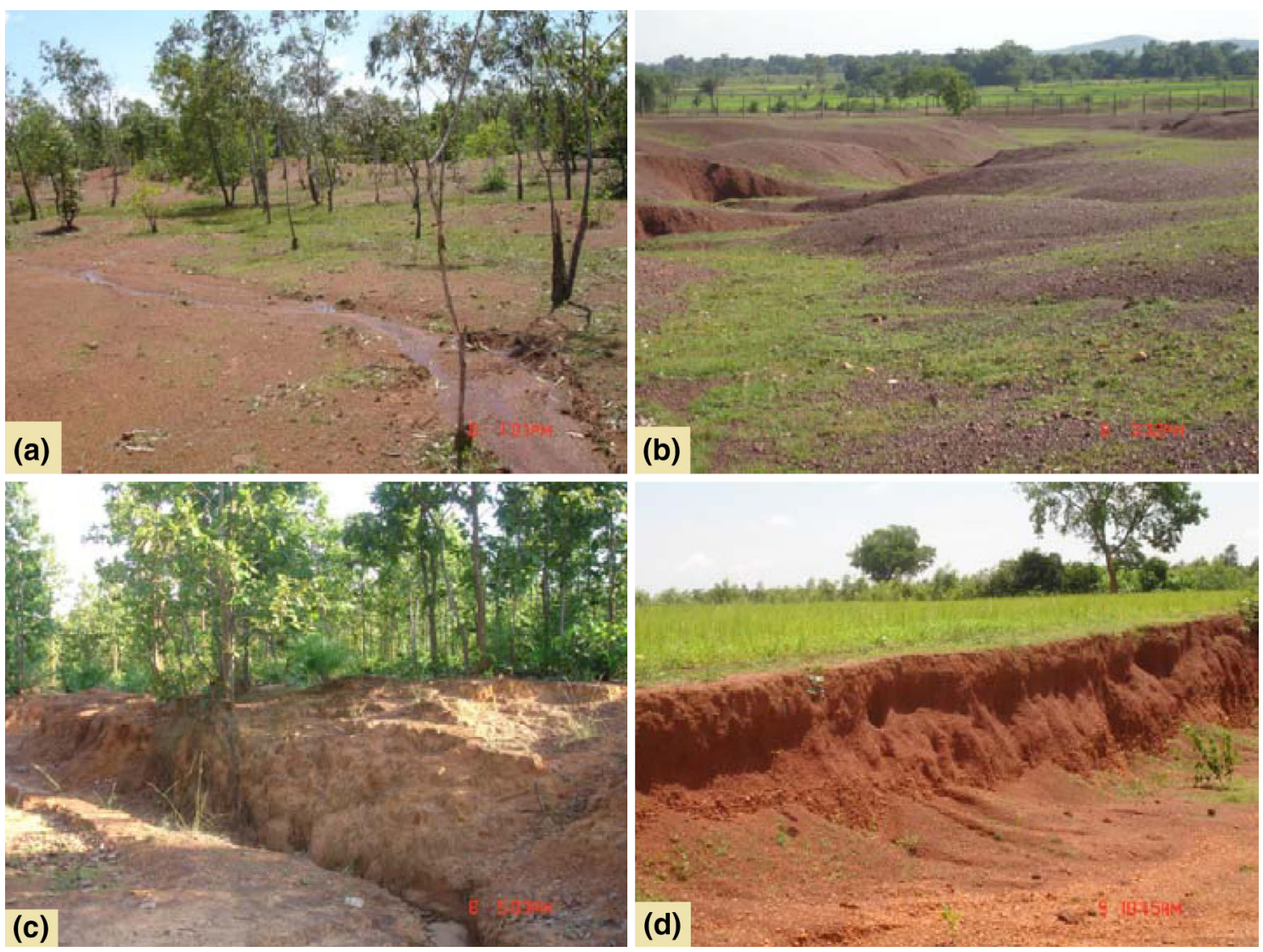

Fig. 6 Types of soil erosion: a Gully erosion in open forest area; b Gully erosion undulating topography; $\mathbf{c}$ Rill erosion in forest fringe area; and d Exposed soil horizon of lateritic platform in agricultural area 
Table 9 General soil erosion management strategies of the study area (modified Rahman et al. 2009)

\begin{tabular}{|c|c|c|c|}
\hline $\begin{array}{l}\text { Erosion } \\
\text { class }\end{array}$ & $\begin{array}{l}\text { Rate of soil erosion } \\
\left(\text { ton } \mathrm{ha}^{-1} \text { year }^{-1} \text { ) }\right.\end{array}$ & Major land use scenario & General management strategies \\
\hline $\begin{array}{l}\text { Slight/ } \\
\text { low }\end{array}$ & $0-2$ & Forest area & $\begin{array}{l}\text { Should be protected from further erosion. Planning should be taken for } \\
\text { restoring degraded vegetation and restoration }\end{array}$ \\
\hline Moderate & $2-5$ & Agricultural land & $\begin{array}{l}\text { There is a probability that the rate of erosion will increase in future in this } \\
\text { area. Therefore, proper land-use planning is needed such as suitable } \\
\text { cropping pattern for agricultural land in local level }\end{array}$ \\
\hline High & $5-10$ & $\begin{array}{l}\text { Agricultural fallow land/ } \\
\text { Barren land }\end{array}$ & $\begin{array}{l}\text { Strictly maintain suitable cropping pattern and crop rotation practice. } \\
\text { Environment Impact Assessment (EIA) must be performed prior to } \\
\text { allocation for the development of any new infrastructure. Community based } \\
\text { soil erosion management program should be introduced and lower cost } \\
\text { erosion control techniques should be applied }\end{array}$ \\
\hline $\begin{array}{l}\text { Very } \\
\text { high }\end{array}$ & $>10$ & $\begin{array}{l}\text { Waste land with/without } \\
\text { lateritic undulating terrain }\end{array}$ & $\begin{array}{l}\text { Priority to be given for soil conservation on emergency basis. To control and } \\
\text { protect areas from severe soil erosion, preference should be given to } \\
\text { agronomic measures of soil conservation, such as conservation tillage, in } \\
\text { conservation planning. Agronomic measures are more suited to existing } \\
\text { farming systems. Some other engineering structures for controlling soil } \\
\text { erosion (terraces, contour bandings or contour hedgerows, etc.) should be } \\
\text { implemented as appropriate }\end{array}$ \\
\hline
\end{tabular}

controls and can be achieved by minimal disruption of natural environments

Acknowledgments The authors gratefully acknowledge the anonymous reviewers for constructive comments and suggestions.

\section{References}

Alexakis DD, Hadjimitsis DG, Agapiou A (2013) Integrated use of remote sensing, GIS and Precipitation Data for the Assessment of Soil Erosion Rate in the Catchment Area of Yialias in Cyprus. Atmos Res 131:108-124

Arnoldus HMJ (1980) An approximation of the rainfall factor in the universal soil loss equation. In: De Boodt and Gabriels: assessment of erosion. FAO Land and Water Development Division, Wiley, England, pp 127-132

Baroudy ELAA, Moghanm FS (2014) Combined use of remote sensing and GIS for degradation risk assessment in some soils of the Northern Nile Delta. J. Remote Sensing Space Sci, Egypt. doi:10.1016/j.ejrs.2014.01.001

Bhunia GS, Shit PK (2013) Identification of temporal dynamics of vegetation coverage using remote sensing and GIS. Int J Cur Res 5(3):652-658

Chatterjee S, Krishna AP, Sharma AP (2014) Geospatial assessment of soil erosion vulnerability at watershed level in some sections of the Upper Subarnarekha river basin, Jharkhand, India. Environ Earth Sci 71:357-374

Chen T, Niu R, Li P, Zhang L, Du B (2010) Regional soil erosion risk mapping using RUSLE, GIS, and remote sensing: a case study in Miyun Watershed, North China. Environ Earth Sci. 63(3):533-541

Dhuruvanarayana VV, Rambabu NP (1983) Estimation of soil erosion in India. J Irrig Drain Engg 109:419-434

Flanagan DC, Nearing MA (1995) USDA-Water erosion prediction project: hillslope and watershedmodel documentation. NSERL Report No. 10.West Lafayette Ind. USDA-ARS National Soil Erosion Research Laboratory

Gayen S, Bhunia GS, Shit PK (2013) Morphometric analysis of kangshabati-darkeswar interfluves area in West Bengal, India using ASTER DEM and GIS Techniques. J Geol Geo Sci 2:133. doi:10.4172/2329-6755.1000133

Gyssels G, Poesen J, Bochet E, Li Y (2005) Impact of plant roots on the resistance of soils to erosion by water: a review. Prog Phys Geog 29:189-217

Jiang L, Yao Z, Liu Z, Wu S, Wang R, Wang L (2015) Estimation of soil erosion in some sections of Lower Jinsha River based on RUSLE. Nat Hazards 76:1831-1847

Kouli M, Soupios P, Vallianatos F (2009) Soil erosion prediction using the Revised Universal Soil Loss Equation (RUSLE) in a GIS framework, Chania, Northwestern Crete, Greece. Environ Geol 57:483-497

McCool DK, Brown LC, Foster GR (1987) Revised slope steepness factor for the Universal Soil Loss Equation. Trans. ASAE 30:1387-1396

Millward AA, Merse JE (2001) Conservation strategies for effective land management of protected areas using an erosion prediction information system (EPIS). J Environ Manage 61:329-343

Moncef B, Leidig M, Gloaguen R (2011) Optimal parameter selection for qualitative regional erosion risk monitoring: a remote sensing study of SE Ethiopia. Geosci Front 2(2):237-245

Mondal S (2012) Remote Sensing and GIS Based Ground Water Potential Mapping of Kangshabati Irrigation Command Area. West Bengal. J Geogr Nat Disast 1:104. doi:10.4172/2167-0587. 1000104

Moore I, Burch G (1986) Physical basis of the length-slope factor in the universal soil loss equation. Soil Soc Am J 50:1294-1298

Morgan RPC, Quinton JN, Rickson JRJ (1992) Soil erosion prediction model for the Europian Community. GB-ISCO-WASWC

Nagaraju MSS, Obi-Reddy GP, Maji AK, Srivastava R, Raja P, Barthwal AK (2011) Soil loss mapping for sustainable development and management of land resources in Warora Tehsil of Chandrapur District of Maharashtra: an integrated approach using remote sensing and GIS. J Ind Soc. Remote Sens. 39(1):51-61

Nandi AS (2012) A study on the changing socio-economic status of local people under the impact of forest degradation and related environmental problems at Jhargram Subdivision. Vidyasagar University, India, West Bengal

Nasre Nagaraju MSS, Srivastava R, Maji AK, Barthwal AK (2013) Soil erosion mapping for land resources management in Karanji 
watershed of Yavatmal district, Maharashtra using remote sensing and GIS techniques. Ind J. Soil Cons. 41(3):248-256

Ozsoy G, Aksoy E, Dirim MS, Tumsavas Z (2012) Determination of soil erosion risk in the Mustafakemalpasa River Basin, Turkey, using the Revised Universal Soil Loss Equation, Geographic Information System, and Remote Sensing. Environ Manag 50:679-694

Pandey A, Chowdary VM, Mal BC (2007) Identification of critical erosion prone areas in the small agricultural watershed using USLE, GIS and remote sensing. Water Resour Manage 21:729-746

Pandey A, Mathur A, Mishra SK, Mal BC (2009) Soil erosion modeling of a Himalayan watershed using RS and GIS. Environ Earth Sci 59(2):399-410

Pandey Y, Imtiyaz M, Dhan D (2011) Prediction of Runoff and Sediment Yield of Ninga Watershed Sone Catchment. Environ Ecol 29(2A):739-744

Pimentel D (2006) Soil erosion: a food and environmental threat. Environ Dev Sustain 8:119-137

Prasannakumar V, Vijith H, Abinod S, Geetha N (2012) Estimation of soil erosion risk within a small mountainous sub-watershed in Kerala, India, using Revised Universal Soil Loss Equation (RUSLE) and geo-information technology. Geosci Front 3(2):209-215

Rabus B, Eineder M, Roth A, Bamler R (2003) The shuttle radar topography mission - a new class of digital elevation models acquired by spaceborne radar. J Photogramm Remote Sens $57: 241-262$

Rahman MDR, Shi ZH, Cai Chongfa (2009) Soil erosion hazard evaluation - an integrated use of remote sensing, GIS and statistical approaches with biophysical parameters towards management strategies. Ecol Model 220:1724-1734

Rao YP (1981) Evaluation of Cropping Management Factor in Universal Soil Loss Equation under Natural Rainfall Condition of Kharagpur, India. In: Proceedings of the South- east Asian Regional Symposium on Problems of Soil Ero- sion and Sedimentation, Bangkok, vol 27-29, pp 241-254

Reddy MS (1999) Theme paper on Water: Vision 2050. Indian Water Resources Society, Roorkee, pp 51-53

Renard KG, Foster GR, Weesies GA, Porter JP (1991) RUSLE, revised universal soil loss equation. J Soil Water Conserv 46(1):30-33

Renard KG, Foster GR, Weesie GA, Mccool DK, Yoder DC (1997) Predicting soil erosion by water: a guide to conservation planning with the Revised Universal Soil Loss Equation (RUSLE). Agriculture Handbook, 703. USDA, Washington

Renard K, Yoder D, Lightle D, Dabney S (2011) Universal soil loss equation and revised universal soil loss equation. Handbook of erosion modelling. Blackwell Publ, Oxford, pp 137-167

Rogan J, Franklin J, Roberts DA (2002) A comparison of methods for monitoring multitemporal vegetation change using Thematic Mapper imagery. Remote Sens Environ 80(1):143-156

Sharma A (2010) Integrating terrain and vegetation indices for identifying potential soil erosion risk area. Geo Spatial Inform Sci 13(3):201-209
Shit PK, Maiti R (2012) Mechanism of Gully-Head Retreat-A Study at GanganirDanga, PaschimMedinipur, West Bengal. Ethiopian J Environ Stud Manag 5(4):332-342

Shit PK, Bhunia GS, Maiti R (2013) Assessing the performance of check dams to control rill-gully erosion: small catchment scale study. Int J Curr Res 5(4):899-906

Shit PK, Paira R, Bhunia GS, Maiti R (2015) Modeling of potential gully erosion hazard using geo-spatial technology at Garbheta block, West Bengal in India. Model Earth Syst Environ 1:2. doi:10.1007/s40808-015-0001-x

Sinha D, Joshi V (2012) Application of Universal Soil Loss Equation (USLE) to Recently Reclaimed Badlands along the Adula and Mahalungi Rivers, Pravara Basin, Maharashtra. J Geol Soc India 80:341-350

Symeonakis E, Drake N (2010) 10-Daily soil erosion modeling over sub-Saharan Africa. Environ Monit Assess 161:369-387

USDA (1978) Predicting Rainfall Erosion Losses. A Guide to Conservation Planning, Washington DC

USDA-SCS (U.S. Department of Agriculture-Soil Conservation Service) (1972) SCS National Engineering Handbook, Section 4, Hydrology. Chapter 10, Estimation of Direct Runoff From Storm Rainfall. U.S. Department of Agriculture, Soil Conservation Service, Washington, D.C., pp 10.1-10.24

Van Der Knijff JM, Jones RJA, Montanarella L (2000) Soil erosion risk assessment in Europe. EUR 19044 EN. Office for Official Publications of the European Communities, Luxembourg, p 34

Van Rompaey A, Bazzoffi P, Jones RJA, Montanarella L (2005) Modeling sediment yields in Italian catchments. Geomorphology 65:157-169

Wang LH, Huang JL, Du Y, Hu YX, Han PP (2013) Dynamic assessment of soil erosion risk using Landsat TM and $\mathrm{HJ}$ satellite data in Danjiangkou Reservoir area, China. Remote Sens 5:3826-3848

Williams JR, Jones CA, Dyke PT (1990) The EPIC model. United States Department of Agriculture (USDA) Technical, Bulletin No 1768

Wischmeier WH, Smith DD (1965) Predicting Rainfall Erosion Losses from Cropland East of the Rocky Mountains. Handbook no. 282. USDA, Washington, DC

Wischmeier WH, Smith DD (1978) Predicting rainfall erosion losses: a guide to conservation planning. USDA, Agriculture Handbook No. 537, Washington, DC

Wischmeier WH, Johnson CB, Cross BV (1971) A soil erodibility nomograph for farmland and construction sites. J Soil Water Conserv 26(5):189-193

Wu W, Shao G (2002) Optimal Combinations of Data, Classifiers, and sampling methods for Accurate Characterizations of deforestation. Canad J Remote Sens 28(4):601-609

Yildirim U (2012) Assessment of soil erosion at the Deðirmen Creek watershed area. Afyonkarahisar, Turkey, pp 73-80 